\title{
Marcel Proust (1871-1922): reassessment of his asthma and other maladies
}

\author{
O.P. Sharma
}

\begin{abstract}
Marcel Proust (1871-1922): reassessment of his asthma and other maladies. O.P. Sharma. (C) ERS Journals Ltd 2000.

ABSTRACT: Marcel Proust endured severe allergies and bronchial asthma from early childhood. Those who suffer from the frightening and recurrent pangs of asthma often become dependent on their parents particularly mother; Proust was no exception. In his time asthma was poorly understood by physicians who considered the illness to be a type of hysteria. Decades later, we now understand that the severe, poorly controlled, suffocating episodes of asthma were responsible for the complex persona that Marcel Proust had assumed.
\end{abstract}

Eur Respir J 2000; 15: 958-960.

\begin{abstract}
Correspondence: O.P. Sharma, USC School of Medicine, LAC+USC Medical Centre, 1200 N. State St., Room 11-900, Los Angeles, CA 90033, USA. Fax: 323 2262738
\end{abstract}

Received: December 211999

Accepted after revision January 172000
Adrien Proust was a famous clinician and epidemiologist. He was Chef de Clinique at the Hospital de la Charite and a consultant at Parvis Notre-Dame and Hotel-Dieu France. Despite a busy clinical practice he devoted much of his time to studying the epidemiology of cholera and bubonic plague. He travelled extensively lecturing and consulting on infectious diseases. He was appointed professor of hygiene at the Medical Faculty in Paris and was awarded Chevalier de la Legion d'Honneur. He wrote extensively covering many aspects of diagnosis and treatment of medical illness, but most authoritatively on epidemiology of infectious diseases. Chauffard, Parrot, Vulpian, and the great diagnostician Potain who pioneered pleural effusion aspirations were his contemporaries. Adrien Proust himself wrote a thesis on pneumothorax.

Adrien Proust married Jeanne Weil, the daughter of a rich Jewish stockbroker Nathé Weil. Marriages between Jewish and gentile families were not infrequent. The arrangement between the Prousts was that, while she wouldn't convert, the children would be brought up as Catholics. The first baby, a boy, was born in July 1871; at the age of four weeks he was baptized at the local church and was named Marcel-Valentin-Louis-Eugene-Georges, [1].

The young Marcel Proust was a sickly child. Recurrent episodes of hay fever and other allergic problems had started to plague him from his early years. Dr Martin, a friend of his father and specialist in treating allergies, cauterized the boy's nose more than one hundred times. After having been subjected to these painful and frightening procedures, the boy was told that he would never again suffer from hay fever. Soon after he was sent to the country for rest. After arrival at the destination, Marcel developed a severe attack of asthma. He had to be immediately transferred back to Paris in a state of near coma. This episode of severe breathlessness at the age of 9 yrs would leave his airways permanently scarred. He never recovered from the persistent hyperexcitability of his airways caused by the initial assault. His asthma attacks became more frequent and began to appear after exposure to dust, pollens, extremes of temperature and humidity, smoke, and exertion. These fits hounded him constantly but particularly during the night. Proust never could master the unpredictability of asthma exacerbations. He was forced to lead a life of exclusion avoiding all contacts with natural and man made agents that provoked asthma.

Not only did Proust suffer from severe bronchospasms and constant breathlessness, he also had to endure distressing insinuations from his family, friends and doctors that his asthma was not real; that it was all a big pretence; and it was all due to his insecure, sensitive and dependent personality. In one of the letters Proust wrote to his mother on September 22, 1899, from Splendide Hotel, Evian-lesBains, "... Constantine said I just imagined that cold air was bad for me, because Papa told everyone that my asthma was purely imaginary. I know only too well when I awake here in the morning that it is quite real..." [2].

His father could not extricate himself from the widespread notion that asthma and hay fever were often no more than nervous afflictions closely allied to a morbid craving for tenderness. An equally ridiculous but popular theory was fashioned by Pierre Merklen, a well known Parisian specialist of pulmonary and cardiac diseases, who asserted that asthma was a nervous habit and that it could be cured in a sanitarium. Proust was advised to go to Berne to be admitted to such a sanitarium for nervous diseases. Dr Dejerine, a famous neurologist, promised to cure Proust in 3 months by subjecting him to isolation. In the later half of the nineteenth century and the early decades of the twentieth century, hysteria and neuroses were causally linked to many physical illnesses including asthma, migraine, tics, epilepsy, and mutism [3].

Thus, it does not come as a surprise that Proust developed a deep distrust in the medical profession, and had no faith in his doctors. He believed that his physicians did not understand the severity of the illness and were tragically immune to his plight as an asthma victim, "the poor suffocating patient who, through eyes filled with tears, smiles at the people who are sympathizing without being able to help him" [4].

Emotional disturbance may play a part in aggravating bronchospasm, but there are no distinct characteristic personality features amongst asthmatic children [5]. Asthma 
is a chronic inflammatory disorder of the airways that is mediated by complex immunological and immunopathological changes sprouting on an appropriately receptive genetic terrain. No amount of emotional disturbance seems to play a major role in initiating a response involving mast cells, eosinophils, T-helper lymphocytes, neutrophils, macrophages, and epithelial cells.

There were many features of Proust's illness that indicated the presence of poorly and inadequately treated asthma. In 1896, he wrote a letter to his mother stating that he was not sleeping well in the night. He used to go to bed at 23:00 h precisely. However, the chest oppression and tightness would wake him up soon after midnight despite extensive fumigation. In order to get some sleep he began taking barbiturates. A short sleep would ensue but by 05:30 h he would be awakened by chest oppression and severe panting. In a letter to his mother, probably written in 1905, he complained that cold air and open windows had brought back his cough. Cough is a common manifestation of bronchospasm. During the winter months his asthma and cough were worse. These episodes lasted for 36 or more hours. It is now established that most patients with asthma develop acute bronchospasm after an exposure to cold [6]. FLOYER [7], three centuries ago, gave a picturesque description of nocturnal asthma occurring in the cold, lonely nights in the English countryside, "I have observed the fit always to happen after sleep in the night where nerves are filled with windy spirits and the heat of the bed has rarified the spirits and humours".

The science of chronobiology deals with the biological processes that have time-related rhythms. Some of these rhythms are yearly, others are monthly, and others follow a $24 \mathrm{~h}$ cycle. In asthma, the $24 \mathrm{~h}$ cycle (circadian) is important. The airways are narrow at 04:00 h [8]. Furthermore, this spasm progressively increases from 00:00 $\mathrm{h}$ to $06: 00$ $\mathrm{h}$, even in a widely awake patient, as long as he remains supine. Sleep aggravates the spasm [9, 10]. This bronchial hyperactivity is also influenced by many factors including, but not limited to, decreased levels of serum cortisol, circulating adrenalin or cyclic adenosine monophosphate (cAMP); and increased histamine concentrations, cholinergic tone, gastroesophageal reflux, increase in airway cooling or lung neutrophils and eosinophils. Furthermore, during the night room allergens, indoor pets and plants, bedding and pillows, carpet and rug mites, and cockroaches tend to provide a concentrated blast of antigenic activity capable of not only initiating bronchial narrowing, but also perpetuating and causing asthma in more unfortunate individuals.

TURNER-WARWICK [11] conducted a survey of 7,729 asthma patients in the UK; $94 \%$ woke up at least one night per month with asthma symptoms, $74 \%$ woke up at least one night per week, $64 \%$ at least three nights per week, and $39 \%$ awoke every night [11]. Marcel Proust's asthma kept him awake every night. The critical period for a patient with poorly controlled asthma is between $00: 00 \mathrm{~h}$ and $06: 00 \mathrm{~h} ; 80 \%$ of the respiratory arrests occurring during this time [12]. In 1900, he wrote to his mother: "..An attack of asthma of unbelievable violence and tenacity-such is the depressing balance-sheet of my night, which it obliged me to spend on my feet in spite of the early hours at which I got up yesterday..." [13]. On August 31, 1901, he again wrote to his mother. "....If it recurred these next few nights, I should be temporarily obliged to give up keeping regular hours, because it so happens that my attack comes on at the dead of night, when there is no one to light my candle or make me a hot drink afterwards...." [14].

Gradually with the passage of time, the attacks of nocturnal asthma were keeping him awake until 02:00 h. He started taking breakfast at 03:00 h. Many of these attacks lasted $48-54 \mathrm{~h}$ at a stretch. Exposure to causative antigen during the day might have caused delayed bronchospasm that occurs many hours later during the night in some patients. An evening allergen exposure leads to a late nocturnal asthmatic response in almost all of the sensitive individuals. With his asthma now out of control, Proust was desperately trying to fight back and finish his work. His isolation became more absolute; he started to withdraw from society. He became dependent on caffeine, barbital, opium-based antiasthma powders, and belladonna and stramonium fumigations. With no fresh air, and almost no exercise he became susceptible to repeated bouts of bronchitis, pneumonia and other respiratory infections. Fever, shaking chills and cough became troublesome. The cork lining of his room might have aggravated his asthma because cork is known to harbour dust and organic molds. The latter are known to cause hypersensitivity pneumonitis. It is conceivable that Proust had developed another lung disease that propelled him towards early respiratory death.

Throughout his life, Proust, besides asthma and allergies, suffered from a long list of illnesses. Never has there been a plausible diagnosis to explain his recurrent and persistent abdominal pains. Marcel's letters to his mother constantly reveal concerns about the stomach pains and digestive problems. His doctors thought that the pains were of emotional origin; however, Proust asserted, "My stomach pains are real, my asthma is real no matter what these fellows say" [3]. He experienced mysterious fevers all his life; most of these episodes had no satisfactory explanation. The presence of albumin in his urine and recurrent, mostly self limiting, joint pains also remain unexplained. In his final years, Proust developed speech difficulties, vertigo, ataxia, facial paralysis, and headaches. I believe that fevers, recurrent abdominal pains, albuminuria and joint pains were due to Familial Mediterranean Fever (FMF).

FMF is not a universal disease, it affects ethnic groups of Middle Eastern and Mediterranean origin, mainly Jews, Armenians, Turks, Druze, and Arabs. In Sepharidic Jews and Armenians, the frequency of the FMF genes reaches 1:20. The clinical picture includes recurrent bouts of fever, severe abdominal, pleural or joint pain. The diagnosis requires a high index of suspicion and is established by exclusion of other inflammatory conditions. Although successful mapping of the FMF gene to the short arm of chromosome 16 has been accomplished, the mechanism of the inflammatory attack remains unknown and the diagnosis is often difficult and based solely on clinical judgement. There is no specific diagnostic test for FMF. Furthermore, only $50 \%$ of the patients have a family history of the disease. Differences in the clinical manifestations of FMF between various population groups also tends to blur the diagnostic picture. For example, arthritis is noted in $75 \%$ of non-Askenazi Jewish patients, but only in $44 \%$ of Turks, $37 \%$ Armenians, and in 33\% of Arabs with FMF. Amyloidosis was found in $80 \%$ of non-Askenazi Jews in the 
precolchicine era and in $60 \%$ of Anatolian Turks, but only in $1.7 \%$ of Arabs. Amyloidosis is not found in Armenian FMF patients living in the USA, but occurs in $25 \%$ of Armenian FMF patients living in Armenia. Transient or persistent albuminuria particularly during attacks, is common in patients with FMF. In 1970, ELIAKIM et al. [14] analyzed renal manifestations in 106 patients with FMF and found that $12.3 \%$ had amyloidosis and $22 \%$ had renal lesions other than amyloid. It is likely that amyloidosis was the cause of Proust's albuminuria. His clinical illness has two essential major criteria needed for the diagnosis of FMF [15]. However, in the absence of any evidence of colchicine effectiveness there will always remain a doubt regarding the firmness of this diagnosis. Nevertheless, as Sherlock Holmes said, "...when you have excluded the impossible, whatever remains, however improbable, must be the truth" [16].

Marcel Proust's total illness was complex. He was violently atopic and suffered from chronic, persistent, poorly treated asthma [17]. Most likely he was also a victim of FMF. Furthermore, he endured the side-effects of caffeine, belladonna, barbital, morphine, hyoscine and others drugs. His distemper was poorly understood, by his family, friends and physicians. The latter, in their zeal and devotion to psychosomatic theories, failed to provide a rational management for his organic illness. The resulting physical and psychological infirmity ended Proust's life at the early age of 51 yrs $[18,19]$.

\section{References}

1. Maurois A. Proust: portrait of a genius. New York, Harper Brothers, 1950.

2. Proust M. Selected letters 1880-1903. Kolb P. Chicago eds. The University of Chicago Press, 1983; p. 205.

3. Straus B. Maladies of Marcel Proust. Doctors and disease in his life and work. New York, Holmes and Meier Publishers, 1980.
4. Hayman R. Proust A Biography. New York, Harper Collins. 1990; p. 18.

5. Kavanagh J, Mattson A. Pychophysiologic disorders. In: Nashpitz J, ed. Basic Handbook of Child Psychiatry Brookline, MA. Blackwell. 1979; p. 35.

6. Chen W, Horton D, Weiser P. Airway obstruction induced by airway cooling in asthmatics. Physiologist 1977; 20: 16-22.

7. Floyer J. A Treatise of the Asthma. London, Wilkin R, Inng W, 1698.

8. Hetzel M, Clark T, Branthwaite M. Asthma: Analysis of sudden deaths and ventilatory arrests in hospital. $B M J$ 1977; 1: 808-811.

9. Ballard R, Saathoff M, Patel D, Kelly P, Martin R. Effect of sleep on nocturnal bronchoconstriction and ventilatory patterns in asthmatics. J Appl Physiol 1989; 67: 243-249.

10. Martin R, Cicutto L, Ballard R. Factors related to the nocturnal worsening of asthma. Am Rev Respir Dis 1990; 141: 33-38.

11. Turner-Warwick M. Epidemiology of nocturnal asthma. Am J Med 1988; 85: 8-18.

12. Hetzel M, Clark T. Comparison of normal and asthmatic circadian rhythms and peak expiratory flow rate. Thorax 1980; 35: 732-738.

13. Hayman R. Proust: A Biography. New York, Harper Collins, 1990

14. Eliakim M, Rachmilewitz M, Rosenmann E, Niv A. Renal manifestations in recurrent polyserositis (Familial Mediterranean Fever). Isr J Med Sci 1970; 6: 228-245.

15. Sohar E, Gafni J, Pras M eds. Familial Mediterranean Fever. London Freund Publishing House Ltd, 1997.

16. Doyle AC. The complete Sherlock Holmes. Vol. 1 New York, Doubleday Co Inc. 1930; pp. 301-318.

17. Tattersfield A, Postma D, Barnes P, et al. Exacerbations of asthma: a descriptive study of 425 severe exacerbations. Am J Respir Crit Care Med 1999; 100: 594-599.

18. Falliers CJ. The literary genius and the many maladies of Marcel Proust: selections and notes. J Asthma 1986; 23: 157-164.

19. De Botton A. How Proust can change your life. London, Picador, Macmillan Publishers Ltd, 1997. 